\title{
Effects of cashew nut testa levels as an alternative to wheat bran in gestating sow diets
}

\author{
Lin Hu Fang ${ }^{1}$, Young Gi Hong ${ }^{1}$, Jin Su Hong ${ }^{1}$, Jae Hark Jeong ${ }^{1}$, Young Geol Han', \\ In Hyuk Kwon', and Yoo Yong Kim ${ }^{1, *}$
}

\author{
* Corresponding Author: Yoo Yong Kim \\ Tel: +82-2-880-4801, Fax: +82-2-878-5839, \\ E-mail: yooykim@snu.ac.kr \\ ${ }^{1}$ College of Agriculture and Life Sciences, Seoul \\ National University, Seoul 08826, Korea \\ ORCID \\ Lin Hu Fang \\ https://orcid.org/0000-0002-3617-7583 \\ Young Gi Hong \\ https://orcid.org/0000-0001-8401-3199 \\ Jin Su Hong \\ https://orcid.org/0000-0002-3401-3024 \\ Jae Hark Jeong \\ https://orcid.org/0000-0001-9611-3787 \\ Young Geol Han \\ https://orcid.org/0000-0001-7869-1938 \\ In Hyuk Kwon \\ https://orcid.org/0000-0002-3240-753X \\ Yoo Yong Kim \\ https://orcid.org/0000-0001-8121-3291
}

Submitted Aug 11, 2017; Revised Oct 23, 2017; Accepted Nov 17, 2017
Objective: This study was conducted to evaluate the effects of dietary cashew nut testa (CNT) as an alternative feed ingredient to wheat bran on reproductive performance, litter performance, milk composition, and blood profiles of gestating sows.

Methods: Forth multiparous sows (Yorkshire $\times$ Landrace) were fed experimental diets starting at 35 days of pregnancy and an initial average body weight (BW) of $211.53 \pm 8.86 \mathrm{~kg}$. Each sow was assigned to a treatment based on BW, backfat thickness (BF) and parity with 10 sows per treatment. Treatments were as follows: i) corn-soybean meal based diet with $6 \%$ of wheat bran (C0); ii) basal diet with $2 \%$ of CNT and $4 \%$ of wheat bran (C2); iii) basal diet with $4 \%$ of CNT and $2 \%$ of wheat bran (C4); and iv) basal diet with $6 \%$ of CNT (C6).

Results: There were no statistically significant differences in BW and BF of gestating sows throughout the experimental period. However, changes in $\mathrm{BF}(\mathrm{p}=0.09)$ and the daily feed intake of sows $(\mathrm{p}=0.09)$ tended to linearly increase during the lactation period. The weaning to estrus interval (WEI) showed a quadratic response to CNT treatment $(\mathrm{p}=0.02)$, and the $\mathrm{C} 2$ diet showed the shortest WEI. Litter birth weight $(\mathrm{p}=0.04)$ and piglet birth weight $(\mathrm{p}$ $=0.06$ ) were linearly decreased with increase in CNT. Furthermore, there had no significant differences in piglet weight and litter weight in 21 day. Insulin concentration at day 70 of gestation was linearly reduced with increasing CNT level in diets $(\mathrm{p}=0.03)$.

Conclusion: When $6 \% \mathrm{CNT}$ replaced wheat bran in gestating sow diets, there were no negative effects on sow performance, but litter birth weight and piglet birth weight were decreased when CNT level increased in gestating sow diets.

Keywords: Cashew Nut Testa; Wheat Bran; Gestating Sow; Lactating Sow; Reproductive Performance

\section{INTRODUCTION}

Feed costs comprise approximately $65 \%$ of total costs for pork production [1]. Therefore, feed plays a major role in the profitability of a swine farm [2]. The price of feedstuff has increased since 2006, as the biofuel industry developed [3]. Several studies have been conducted to find alternative ingredients for reducing the cost of feed, such as cocoa pod husks, brewers spent grains, rice bran and maize bran [4-8].

In Korea, high fiber feedstuffs, particularly wheat bran, which contains $7.77 \%$ crude fiber, are frequently added to gestating sow diets to prevent constipation [9]. Cashew nut testa (CNT) is one of the by-products obtained from processing cashew nuts, but it has not been considered as monogastric animal feed. The CNT is a reddish-brown skin that covers the cashew kernel. This skin is reported to be rich in hydrolysable tannins and polyphenols, and it contains over $10.3 \%$ crude fiber, which is higher than wheat bran [1]. It has rarely been considered as a feed ingredient in monogastric animals due to its high fiber content [1]. How- 
ever, as the price of grain has been unstable, it is important to find a cheaper alternative ingredient that contains optimum fiber content to replace wheat bran in gestating sow diets. The production of cashew nuts has rapidly increased in recent years, because more and more people know cashew nuts which have great nutrients and are good for health. The CNT is cheaper than wheat bran; therefore, inclusion of CNT in gestating sow feeds could reduce the cost of feeding.

Therefore, this study was conducted to evaluate the effects of dietary $\mathrm{CNT}$ as an alternative feed ingredient to wheat bran on reproductive performance, litter performance, milk composition, and blood profiles of gestating sows.

\section{MATERIALS AND METHODS}

\section{Experimental animals and housing environment}

All experimental procedures involving animals were conducted in accordance with the Animal Experimental Guidelines provided by the Seoul National University Institutional Animal Care and Use Committee (SNUIACUC; SNU-160613-9). A total of 40 multiparous sows (YorkshirexLandrace) with body weights (BW) at $211.53 \pm 8.86 \mathrm{~kg}$ were used. Each sow was kept in an individual gestation stall $\left(2.4 \times 0.64 \mathrm{~m}^{2}\right)$ with a feeder and water nipple. Second parity sows were fed $2.2 \mathrm{~kg} / \mathrm{d}$ and over 3 to 6 parity sows were fed $2.4 \mathrm{~kg} / \mathrm{d}$. On day 110 of gestation, sows were moved into environmentally controlled farrowing rooms and placed in individual farrowing crates $\left(2.5 \times 1.8 \mathrm{~m}^{2}\right)$. Each farrowing crate was equipped with a feeder and water nipple.

\section{Experimental design, treatment and animal management}

A total of 40 multiparous sows (Yorkshire $\times$ Landrace) were assigned to one of four treatments, 10 sows per treatment, with similar BW, backfat thickness (BF) and parity in a completely randomized design (CRD). Sows in each treatment were in similar average BW, BF, and parity. The experimental diet was added and formulated based on corn-soybean meal, which contained 3,265 kcal of metabolizable energy (ME)/kg, 12.90\% crude protein, $0.74 \%$ total lysine, $0.20 \%$ total methionine, $0.90 \%$ calcium, and $0.70 \%$ total phosphorus. Four diet treatments were formulated with $0 \%, 2 \%, 4 \%$, and $6 \%$ of CNT along with $6 \%, 4 \% 2 \%$, and $0 \%$ of wheat bran, respectively. All nutrients were formulated to meet or exceed NRC requirements [10]. The formula and chemical composition of experimental diets are presented in Table 1 and 2. Chemical composition of cashew nut teast and wheat bran showed in Table 3.

Sows were housed in temperature-controlled rooms with automatic fans used to regulate air flow and placed in an individual crate $\left(2.4 \times 0.64 \mathrm{~m}^{2}\right)$ installed on a concrete floor. After 110 days of gestation, sows were washed and placed into farrowing crates $\left(2.5 \times 1.8 \mathrm{~m}^{2}\right)$.
Table 1. Formulation of experimental diets for gestating sow

\begin{tabular}{|c|c|c|c|c|}
\hline \multirow{2}{*}{ Item } & \multicolumn{4}{|c|}{ Cashew nut testa $(\%)$} \\
\hline & 0 & 2 & 4 & 6 \\
\hline \multicolumn{5}{|l|}{ Ingredient (\%) } \\
\hline Corn & 72.63 & 73.39 & 74.14 & 74.20 \\
\hline Soybean meal & 14.75 & 14.77 & 14.79 & 14.81 \\
\hline Tallow & 2.65 & 1.83 & 1.02 & 0.90 \\
\hline Wheat bran & 6.00 & 4.00 & 2.00 & 0.00 \\
\hline Cashew nut testa & 0.00 & 2.00 & 4.00 & 6.00 \\
\hline L-lysine $\mathrm{HCl}$ & 0.17 & 0.17 & 0.17 & 0.17 \\
\hline DL-methionine & 0.03 & 0.03 & 0.03 & 0.03 \\
\hline Mono-dicalcium phosphate & 1.80 & 1.84 & 1.92 & 2.00 \\
\hline Limestone & 1.37 & 1.37 & 1.33 & 1.29 \\
\hline Vit. Mix ${ }^{1)}$ & 0.10 & 0.10 & 0.10 & 0.10 \\
\hline Min. $\operatorname{Mix}^{2)}$ & 0.10 & 0.10 & 0.10 & 0.10 \\
\hline Choline chloride- 50 & 0.10 & 0.10 & 0.10 & 0.10 \\
\hline Salt & 0.30 & 0.30 & 0.30 & 0.30 \\
\hline Total & 100.00 & 100.00 & 100.00 & 100.00 \\
\hline
\end{tabular}

After farrowing, sow lactation diet were restricted to $1 \mathrm{~kg}$ on the first day and gradually increased by $1.0 \mathrm{~kg}$ per day for the first 5 days, with no limitation during the remaining lactation period. Each sow lactated 11 or 12 healthy piglets in this experiment. Within 24 hours of farrowing, Fe-dextran (150 ppm) was administered and treatments such as ear-notching, clipping of needle teeth and tails were conducted. Piglets were

Table 2. Chemical composition of experimental diets for gestating sows

\begin{tabular}{lcccc}
\hline \multirow{2}{*}{ Item } & \multicolumn{4}{c}{ Cashew nut testa (\%) } \\
\cline { 2 - 5 } & $\mathbf{0}$ & $\mathbf{2}$ & $\mathbf{4}$ & $\mathbf{6}$ \\
\hline Chemical composition (calculated value) & & & \\
Metabolizable energy (kcal/kg) & 3,265 & 3,265 & 3,265 & 3,265 \\
Crude protein (\%) & 12.89 & 12.89 & 12.89 & 12.89 \\
Crude ash (\%) & 5.56 & 5.55 & 5.55 & 5.54 \\
Crude fiber (\%) & 2.69 & 2.86 & 2.99 & 3.06 \\
Neutral detergent fiber (\%) & 12.13 & 12.29 & 12.46 & 12.63 \\
Acid detergent fiber (\%) & 3.75 & 3.79 & 3.82 & 3.85 \\
Total lysine & 0.74 & 0.74 & 0.74 & 0.74 \\
Total methionine & 0.23 & 0.23 & 0.23 & 0.23 \\
Calcium & 0.91 & 0.91 & 0.91 & 0.91 \\
Total phosphorus & 0.70 & 0.70 & 0.70 & 0.70 \\
Chemical composition (analyzed value) & & & \\
Crude protein (\%) & 11.84 & 13.02 & 12.76 & 13.46 \\
Crude ash (\%) & 3.33 & 4.24 & 5.00 & 4.81 \\
Crude fiber (\%) & 3.36 & 3.78 & 3.35 & 3.37 \\
Neutral detergent fiber (\%) & 15.55 & 17.86 & 19.28 & 18.15 \\
Acid detergent fiber (\%) & 3.67 & 4.70 & 4.46 & 4.51 \\
Calcium & 1.36 & 1.32 & 1.34 & 1.37 \\
Total phosphorus & 0.72 & 0.73 & 0.72 & 0.71 \\
\hline
\end{tabular}


Table 3. Chemical composition of cashew nut teast and wheat bran

\begin{tabular}{|c|c|c|}
\hline Item & Cashew nut testa & Wheat bran \\
\hline Dry matter ${ }^{1)}(\%)$ & 88.3 & 88.8 \\
\hline Crude protein ${ }^{1)}(\%)$ & 13.32 & 15.00 \\
\hline Crude fat $^{1)}(\%)$ & 9.44 & 3.70 \\
\hline Crude fiber ${ }^{1)}(\%)$ & 11.07 & 9.64 \\
\hline $\operatorname{Ash}^{11}(\%)$ & 2.16 & 4.67 \\
\hline Metabolizable energy ${ }^{11}$ (kcal/kg) & 2,765 & 2,290 \\
\hline Calcaum $^{1)}(\%)$ & 0.10 & 0.11 \\
\hline Phosphorus ${ }^{1)}(\%)$ & 0.16 & 1.02 \\
\hline Acid detergent fiber ${ }^{1)}(\%)$ & 14.91 & 14.30 \\
\hline Neutral detergent fiber ${ }^{1)}(\%)$ & 40.23 & 40.30 \\
\hline $\operatorname{Tannin}^{2)}(\%)$ & 22.03 & - \\
\hline
\end{tabular}

1) Analyzed value.

${ }^{2)}$ Analyzed by Korea Feed Ingredient Association.

weaned at approximately $24 \pm 2$ days, and sows were transferred to a gestating crate.

\section{Measurements and analysis}

Gestation and lactation period, BW (BI-2RB., BI series., ECAS CO., Ltd., Seoul, Korea) and BF (P2 position, Renco Crop., Minneapolis., MN, USA) of sows were measured and blood samples were collected at day 35,70 , and 110 of gestation; at 24 hours post farrowing and at days 21 of lactation. The number of piglets born alive, still born, mummified fetuses, total born, and their BW were measured at 24 hours post farrowing and days 21 of lactation. Individual piglet weight and litter size of lactating sows were recorded postpartum and at day 21 of lactation. The weaning to estrus interval (WEI) of sows was recorded after weaning, as this is an important parameter for reproductive performance. Voluntary feed intake of sows was measured during lactation.

Gestating and lactating sows were bled from the anterior vena cava. Blood samples were collected in disposable culture tubes, centrifuged at $1,500 \mathrm{~g}$ for $15 \mathrm{~min}$, and plasma was harvested from all blood samples and stored at $-20^{\circ} \mathrm{C}$ until analysis. After an injection of oxytocin (Komi oxytocin inj. Komipharm International Co., Ltd., Siheung, Korea), colostrum and milk samples were collected into a falcon tube (Milkoscan FT 120., FOSS, Hillerod, Demark) and stored at $-20^{\circ} \mathrm{C}$ until analysis.

Serum insulin was assayed using Coat-A-Count insulin kits (DPC, Los Angeles, CA, USA). Glucose concentrations were analyzed using a blood analyzer (enzymatic kinetic assay, Roche, Germany).

Colostrum and milk samples were taken from functional mammary glands of each sow at 24 hour post farrowing and at days 21 of lactation, respectively. After collection, samples were stored in a freezer $\left(-20^{\circ} \mathrm{C}\right)$ until further analysis. Proximate analysis of colostrum and milk was conducted using Milkoscan FT 120 (FOSS, Denmark).

\section{Statistical analysis}

Data were analyzed by analysis of variance using the general linear model procedure of SAS (SAS Institute Inc., Cary, NC, USA). Least squares means were calculated for each independent variable. Orthogonal polynomial contrasts were used to determine linear and quadratic effects by increasing dietary CNT levels during gestation for all measurements of sows and piglets. Individual sows and their litters were used as the experimental unit. Alpha was 0.05 and tendency for all analyses was $\mathrm{p} \geq 0.05$ and $\mathrm{p}<0.10$.

\section{RESULTS AND DISCUSSION}

\section{The different of chemical composition between CNT and wheat bran}

The analytical data for CNT, in comparison of wheat bran, was showed in Table 3. Compared to wheat bran, CNT contained more fiber and fat but had less protein ash and phosphorus. The calculated ME content of CNT was higher than that of wheat bran. This may be due to higher contents of fat in CNT.

\section{Sows performance}

The effects of CNT supplementation on BW, BF, WEI, and average daily feed intake (ADFI) in gestating to lactating sows are shown in Table 4 and 5 . There were no significant differences in BW and BW change of sows from gestating day 35 to day 21 of lactation. Body weight change of sows decreased linearly $(p=0.09)$. Generally, the BW of the sows at weaning was reduced compared with the weight at parturition. This is because more nutrients were expended than that obtained through feed [10]. Therefore, nutrients accumulated in the body were mobilized for lactation [11,12]. Body weight loss can have a negative effect on WEI [13].

Average daily feed intake of lactating sows linearly increased with increased CNT levels of pregnant sow diets $(\mathrm{p}=0.09)$. Although not statistically significant, sows being fed CNT during the gestation period had increased lactating sow ADFI compared with the control group. Generally, if feed intake is too low, there is a negative effect on body condition with an increased WEI $[14,15]$ and decreased ovulation [16]. In this experiment, the percentage of CNT in gestating sow diet showed a quadratic response on WEI. The WEI was shortest in $2 \%$ CNT, suggesting that the ADFI of sows affected the WEI.

Higher fiber diets during gestation have been shown to increase feed intake during lactation $[17,18]$. In this experiment, neutral detergent fiber (NDF) and acid detergent fiber (ADF) levels improved with increased dietary CNT levels in gestating sow diet compared with wheat bran, but crude fiber percentage was similar among treatments. Renteria-Flores et al [19] reported that improved soybean hulls in gestating sow diets increased NDF and ADF levels, improved ADFI during lactation, and reduced BW loss during lactation. However, a 
Table 4. Effects of cashew nut testa level on body weight and back-fat thickness in gestating sows

\begin{tabular}{|c|c|c|c|c|c|c|c|}
\hline \multirow{2}{*}{ Item } & \multicolumn{4}{|c|}{ Cashew nut testa $(\%)$} & \multirow{2}{*}{ SEM } & \multicolumn{2}{|c|}{$p$-value } \\
\hline & 0 & 2 & 4 & 6 & & Lin. & Quad \\
\hline No. of sows & 10 & 10 & 10 & 10 & - & - & - \\
\hline \multicolumn{8}{|c|}{ Body weight $(\mathrm{kg})$ in gestating sows } \\
\hline Day 35 & 212.2 & 210.3 & 211.0 & 212.5 & 3.52 & 0.96 & 0.83 \\
\hline Day 70 & 230.3 & 230.2 & 224.8 & 228.7 & 3.57 & 0.77 & 0.79 \\
\hline Day 110 & 257.3 & 261.2 & 251.4 & 253.7 & 3.44 & 0.55 & 0.91 \\
\hline 35 to 110 day change & 45.1 & 50.9 & 40.4 & 41.2 & 1.61 & 0.12 & 0.43 \\
\hline \multicolumn{8}{|c|}{ Backfat thickness $(\mathrm{mm})$ in gestating sows } \\
\hline Day 35 & 17.35 & 17.90 & 19.75 & 17.65 & 0.858 & 0.74 & 0.48 \\
\hline Day 70 & 16.95 & 17.40 & 19.45 & 16.35 & 0.882 & 0.98 & 0.34 \\
\hline Day 110 & 19.80 & 18.15 & 18.94 & 18.20 & 0.950 & 0.67 & 0.83 \\
\hline 35 to 110 day change & 2.45 & 0.25 & -0.81 & 0.55 & 0.600 & 0.25 & 0.17 \\
\hline
\end{tabular}

SEM, standard error of mean.

separate study showed that adding sugar beet pulp (27.2\%) and soybean hulls $(19.05 \%)$ to improve crude fiber (3\% to $6 \%$ ), $\mathrm{ADF}$ (6\% to $9 \%$ ) and $\mathrm{NDF}$ (5\% to $7 \%$ ) levels in gestating sows had no effect on BW change, ADFI, and WEI [20]. This finding suggests that fiber type may be more important than concentration on ADFI and WEI of gestation sows.

\section{Reproductive performance and piglet growth performance}

The effects of dietary CNT levels on total born per litter, litter weight, litter weight gain, average BW per piglet and average BW gain of piglet are shown in Table 6. This is the first study investigating effects of CNT level on piglet weight. There were no significant differences in total born per litter, number of alive or number of weaned piglets. Previous studies reported no effects on reproductive performance and piglet performance with increased fiber, ADF and NDF concentrations in gestating sow diets $[19,20]$.

Litter birth weight linearly decreased with increasing CNT $(p=0.04)$ and there was no significant trend in response to
CNT after 21 days of lactation. For litter weight gain, the results were similar among all treatments. The addition of $0 \%$ to $4 \% \mathrm{CNT}$ in gestating diets does not negatively affect litter birth weight, and $6 \%$ CNT had no negative effects on litter weight gain during lactation.

Piglet birth weight linearly decreased with increasing CNT in gestating diets $(p=0.06)$. Piglet weight after cross-fostering showed a linear decrease as the level of CNT increased (p $=0.01)$ and the control group had the highest weight after cross-fostering $(\mathrm{p}<0.01)$. Danielsen and Vestergaard [13] reported that high fiber diets (sugar beet pulp and mixed fiber sources) did not affect total number of piglets born and weaning, but weight of piglets at birth was negatively affected. In this study, there were no significant differences among all treatments on piglet weight at day 21 and piglet weight gain. Consequently, supplementation of dietary CNT levels had no negative effects on nursing piglets during lactation.

\section{Milk composition}

The effects of dietary CNT levels on the chemical composition

Table 5. Effects of cashew nut testa level on body weight, back-fat thickness, weaning to estrus interval and daily feed intake in lactating sows

\begin{tabular}{|c|c|c|c|c|c|c|c|}
\hline \multirow{2}{*}{ Item } & \multicolumn{4}{|c|}{ Cashew nut testa (\%) } & \multirow{2}{*}{ SEM } & \multicolumn{2}{|c|}{ p-value } \\
\hline & 0 & 2 & 4 & 6 & & Lin. & Quad. \\
\hline No. of sows & 10 & 10 & 10 & 10 & - & - & - \\
\hline \multicolumn{8}{|l|}{ Body weight $(\mathrm{kg})$ in lactating sows } \\
\hline 24 hour postpartum & 230.0 & 233.8 & 223.2 & 227.2 & 3.73 & 0.61 & 0.99 \\
\hline Day 21 of lactation & 210.3 & 218.7 & 212.6 & 215.7 & 3.65 & 0.77 & 0.74 \\
\hline Farrowing to day 21 & -19.7 & -15.1 & -10.6 & -11.5 & -1.98 & 0.09 & 0.47 \\
\hline \multicolumn{8}{|l|}{ Backfat thickness $(\mathrm{mm})$ in lactating sows } \\
\hline 24 hour postpartum & 17.90 & 18.30 & 18.75 & 18.85 & 0.902 & 0.71 & 0.93 \\
\hline Day 21 of lactation & 15.45 & 16.30 & 18.13 & 16.30 & 0.772 & 0.57 & 0.44 \\
\hline Farrowing to day 21 & -2.45 & -2.00 & -0.62 & -2.55 & -0.554 & 0.84 & 0.32 \\
\hline Daily feed intake in lactation $(\mathrm{kg} / \mathrm{d})$ & 4.20 & 5.14 & 5.02 & 5.14 & 0.181 & 0.09 & 0.24 \\
\hline Weaning to estrus interval (d) & 6.00 & 4.93 & 5.30 & 5.7 & 0.163 & 0.69 & 0.02 \\
\hline
\end{tabular}

SEM, standard error of mean. 
Table 6. Effects of cashew nut testa level on reproductive and litter performance in gestating to lactating sows

\begin{tabular}{|c|c|c|c|c|c|c|c|}
\hline \multirow{2}{*}{ Item } & \multicolumn{4}{|c|}{ Cashew nut testa $(\%)$} & \multirow{2}{*}{ SEM } & \multicolumn{2}{|c|}{$p$-value } \\
\hline & 0 & 2 & 4 & 6 & & Lin. & Quad. \\
\hline No. of sows & 10 & 10 & 10 & 10 & - & - & - \\
\hline \multicolumn{8}{|c|}{ Reproductive performance } \\
\hline Total born/L & 14.00 & 15.40 & 15.78 & 13.90 & 0.492 & 0.99 & 0.15 \\
\hline No. of born alive & 13.00 & 13.80 & 14.25 & 13.10 & 0.374 & 0.40 & 0.49 \\
\hline No. of stillbirths & 1.00 & 1.60 & 1.53 & 0.80 & 0.222 & 0.96 & 0.24 \\
\hline After cross-foster & 11.90 & 11.90 & 11.85 & 11.80 & 0.083 & 0.62 & 0.87 \\
\hline Day 21 of lactation & 11.40 & 11.10 & 11.50 & 10.50 & 0.183 & 0.15 & 0.33 \\
\hline \multicolumn{8}{|l|}{ Litter weight (kg) } \\
\hline Litter birth weight & 21.79 & 21.72 & 21.07 & 18.26 & 0.059 & 0.04 & 0.26 \\
\hline After cross-foster & $19.30^{\mathrm{A}}$ & $17.80^{A B}$ & $16.22^{B}$ & $16.17^{B}$ & 0.038 & 0.01 & 0.30 \\
\hline Day 21 of lactation & 55.93 & 56.65 & 55.36 & 52.69 & 1.752 & 0.48 & 0.62 \\
\hline Litter weight gain & 36.63 & 38.85 & 39.14 & 36.52 & 1.563 & 0.99 & 0.44 \\
\hline \multicolumn{8}{|l|}{ Piglet weight (kg) } \\
\hline Piglet birth weight & 1.59 & 1.42 & 1.34 & 1.39 & 0.044 & 0.06 & 0.18 \\
\hline After cross-foster & $1.62^{\mathrm{A}}$ & $1.50^{\mathrm{AB}}$ & $1.37^{B}$ & $1.37^{B}$ & 0.031 & 0.01 & 0.28 \\
\hline Day 21 of lactation & 4.90 & 5.09 & 4.78 & 4.94 & 0.098 & 0.85 & 0.92 \\
\hline Piglet weight gain & 3.28 & 3.59 & 3.41 & 3.57 & 0.087 & 0.41 & 0.68 \\
\hline
\end{tabular}

SEM, standard error of mean.

$A, B$ Means with different superscripts within the same row significantly differ $(p<0.01)$.

of sow milk are shown in Table 7. At 24 hour postpartum and day 21 of lactation, there were no significant differences in percentage of casein, protein and solids-not-fat with increasing dietary CNT levels. However, the percentage of fat (24 hour postpartum: $\mathrm{p}=0.03$, day 21 of lactation: $\mathrm{p}=0.06$ ), lactose (24 hour postpartum: $\mathrm{p}=0.02)$ and total solid $(24$ hour postpartum: $\mathrm{p}=0.03$, day 21 of lactation: $\mathrm{p}=0.07$ ) showed quadratic correlation with increasing CNT levels during gestation. Generally, the composition of sow milk depends on the body condition of the sow [21-23] which directly affects piglet growth performance [23]. In this study, there were no significant differences on litter weight gain or piglet weight

Table 7. Effect of cashew nut testa level on milk composition of gestating and lactating sows

\begin{tabular}{|c|c|c|c|c|c|c|c|}
\hline \multirow{2}{*}{ Item } & \multicolumn{4}{|c|}{ Cashew nut testa $(\%)$} & \multirow{2}{*}{ SEM } & \multicolumn{2}{|c|}{ p-value } \\
\hline & 0 & 2 & 4 & 6 & & Lin. & Quad. \\
\hline No. of sows & 10 & 10 & 10 & 10 & - & - & - \\
\hline \multicolumn{8}{|l|}{ Casein (\%) } \\
\hline 24 hour postpartum & 4.98 & 4.49 & 4.22 & 6.07 & 0.321 & 0.32 & 0.10 \\
\hline Day 21 of lactation & 4.36 & 4.57 & 4.30 & 4.22 & 0.073 & 0.22 & 0.26 \\
\hline \multicolumn{8}{|l|}{ Fat (\%) } \\
\hline 24 hour postpartum & 7.62 & 5.27 & 7.11 & 8.24 & 0.482 & 0.25 & 0.03 \\
\hline Day 21 of lactation & 6.18 & 7.35 & 6.44 & 6.29 & 0.198 & 0.68 & 0.06 \\
\hline \multicolumn{8}{|l|}{ Protein (\%) } \\
\hline 24 hour postpartum & 6.37 & 5.76 & 5.23 & 7.91 & 0.438 & 0.31 & 0.10 \\
\hline Day 21 of lactation & 4.81 & 5.00 & 4.72 & 4.61 & 0.082 & 0.22 & 0.35 \\
\hline \multicolumn{8}{|l|}{ Lactose (\%) } \\
\hline 24 hour postpartum & 4.48 & 4.66 & 4.77 & 4.17 & 0.081 & 0.22 & 0.02 \\
\hline Day 21 of lactation & 6.22 & 6.06 & 6.25 & 6.09 & 0.044 & 0.49 & 0.95 \\
\hline \multicolumn{8}{|l|}{ Total solid (\%) } \\
\hline 24 hour postpartum & 20.28 & 17.30 & 18.57 & 22.68 & 0.852 & 0.21 & 0.03 \\
\hline Day 21 of lactation & 18.29 & 19.71 & 18.49 & 18.06 & 0.267 & 0.38 & 0.07 \\
\hline \multicolumn{8}{|l|}{ Solid-not-fat (\%) } \\
\hline 24 hour postpartum & 10.86 & 10.56 & 10.01 & 12.15 & 0.365 & 0.34 & 0.14 \\
\hline Day 21 of lactation & 11.10 & 11.19 & 11.07 & 10.88 & 0.049 & 0.09 & 0.16 \\
\hline
\end{tabular}

SEM, standard error of mean. 
Table 8. Effect of cashew nut testa level on blood profiles of gestating and lactating sows

\begin{tabular}{|c|c|c|c|c|c|c|c|}
\hline \multirow{2}{*}{ Item } & \multicolumn{4}{|c|}{ Cashew nut testa } & \multirow{2}{*}{ SEM } & \multicolumn{2}{|c|}{$p$-value } \\
\hline & 0 & 2 & 4 & 6 & & Lin. & Quad. \\
\hline \multicolumn{8}{|l|}{ Insulin ( $\mu \mathrm{L} \mathrm{U} / \mathrm{L})$} \\
\hline Day 35 & 0.065 & 0.065 & 0.065 & 0.065 & - & - & - \\
\hline Day 70 & 0.088 & 0.086 & 0.054 & 0.059 & 0.0071 & 0.03 & 0.73 \\
\hline Day 110 & 0.079 & 0.081 & 0.062 & 0.075 & 0.0082 & 0.62 & 0.68 \\
\hline 24 hour postpartum & 0.081 & 0.102 & 0.087 & 0.093 & 0.0811 & 0.84 & 0.75 \\
\hline Day 21 of lactation & 0.095 & 0.087 & 0.088 & 0.061 & 0.0948 & 0.14 & 0.51 \\
\hline \multicolumn{8}{|l|}{ Glucose (mg/dL) } \\
\hline Day 35 & 71.167 & 71.167 & 71.167 & 71.167 & - & - & - \\
\hline Day 70 & 66.500 & 68.500 & 67.250 & 67.250 & 1.2579 & 0.92 & 0.65 \\
\hline Day 110 & 79.750 & 77.000 & 76.250 & 74.750 & 1.3148 & 0.28 & 0.84 \\
\hline 24 hour postpartum & 84.750 & 95.500 & 83.000 & 89.750 & 2.2502 & 0.95 & 0.81 \\
\hline Day 21 of lactation & 82.667 & 74.500 & 74.250 & 78.250 & 3.4723 & 0.34 & 0.07 \\
\hline
\end{tabular}

SEM, standard error of mean.

gain during lactation period. Consequently, supplementation of dietary CNT levels did not have negative effects on piglet growth performance, therefore, it was also considered that there were no negative effects on milk quality.

\section{Blood profiles of sows}

The effects of dietary CNT levels on blood insulin and glucose concentration during the gestation-lactation period are shown in Table 8. At day 70 of gestation, blood insulin concentration was linearly reduced with increasing levels of CNT $(p=0.03)$, but from 110 day of gestation to day 21 of lactation, there were no significant differences. Insulin concentration is associated with the breast, metabolism and fat synthesis [24]. In this experiment, because there were no significant differences in BW and $\mathrm{BF}$ at day 70 , the decrease of insulin did not seem to negatively affect sows.

Blood glucose concentration did not show any significant trends from day 70 of gestation to day 21 of lactation. Previous studies have reported that blood glucose concentration decreased with increasing insulin in sows $[25,26]$. In this study, there were no differences in blood insulin and glucose concentration in each treatment, but blood insulin concentration linearly decreased with increasing CNT levels at day 70 of gestation. However, Long et al [27] found that insulin and glucose concentrations from 0.051 ( $\mu \mathrm{L} \mathrm{U} / \mathrm{L})$ to $0.114(\mu \mathrm{L} \mathrm{U} / \mathrm{L})$ in gestating sows had no negative effects on performance. High concentrations of blood insulin and glucose showed no detrimental effects on sow or litter performance. Consequently, supplementation of dietary CNT levels had no negative effects on blood glucose concentration and blood profile of sow.

\section{CONCLUSION}

When $6 \%$ CNT replaced wheat bran in gestating sow diets, there were no negative effects on sow and piglet performance and ADFI during lactation improved, but litter birth weight and piglet birth weight were decreased when CNT level increased in gestating sow diets.

\section{CONFLICT OF INTEREST}

We certify that there is no conflict of interest with any financial organization regarding the material discussed in the manuscript.

\section{ACKNOWLEDGMENTS}

This research was supported by "Cooperative Research Program for Agriculture Science and Technology Development (Project No. PJ011617012016)" Rural Development Administration, Republic of Korea.

\section{REFERENCES}

1. Armstrong D, Attoh-Kotoku V, Kwame RO, Gascar R. Evaluation of nutritional quality of dried cashew nut testa using laboratory rat as a model for pigs. Sci World J 2012;2012: Article ID 984249.

2. Stein HH. Distillers dried grains with solubles (DDGS) in diets fed to swine. Swine Focus 2007;001.

3. Patience JF. Managing energy intake and costs of grow-finish pigs. Adv Pork Prod 2013;24:29-35.

4. Okon BI, Ogunmodede BK. Effects of replacing dietary fish meal with periwinkle flesh on the performance of broiler chickens [BSc Dissertation]. Ibadan, Nigeria: University of Ibadan; 1995.

5. Nelson FS, Ameleke GY, Donkoh A, Lamptey V. Use of locally available agro-industrial by-products (AIBPs) for egg production in the western region of Ghana. The results of an onfarmtrial in Proceedings of the Ghana Society of Animal Prod- 
uction Symposium. 2007;15:103-7.

6. Rhule SWA, Okai DB, Addo-Kwafo S, Ameleke GY. Feed package for pigs in Ghana using AIBPs: solution to feeding constraints. In Proceedings of the Ghana Society of Animal Production Symposium. 2007:15:135-9.

7. Donkoh A, Attoh-Kotoku V. Nutritive value of feedstuffs for poultry in Ghana: chemical composition, apparent metabolizable energy and ileal amino acid digestibility. Livest Res Rural Dev 2009;21:Article \#32.

8. Donkoh A, Zanu HK. Development of feed package for layers using low energy agro-industrial by products. African J Agric Res 2010:5:2782-6.

9. Kim YY. Swine management and nutrition. Seoul, Korea: Seoul National University Press; 2012.

10. Committee on Nutrient Requirements of Swine, National Research Council. Nutrient requirements of swine. 10th ed. Washington, DC, USA: National Academy Press; 1998.

11. Mullan BP, Williams IH. The effect of body reserves at farrowing on the reproductive performance of first-litter sows. Anim Prod 1989;48:449-57.

12. Yang H, Eastham AR, Phillips A, Whittmore CT. Reproductive performance, body weight and body condition of breeding sows with differing body fatness at parturition, differing nutrition during lactation, differing litter size. Anim Prod 1989;48: 181-201.

13. Stevenson JS, Britt JB. Interval to estrus in sows and performance of pigs after alteration of litter size during late lactation. J Anim Sci 1981;53:177-81.

14. King RH, Williams HI. The effects of nutrition on the reproductive performance of first litter sows, 2. Protein and energy intakes during lactation. Anim Prod 1984;38:249-56.

15. Baidoo SK, Aherne FX, Kirkwood RN, Foxcroft GR. Effect of feed intake during lactation and after weaning on sow reproductive performance. Can J Anim Sci 1992;72:911-7.

16. Foxcroft GR, Aherne FX, Clowes EC, Miller H, Zak LJ. Sow fertility: the role of suckling inhibition and metabolic status. In: Ivan M, editor. Animal science research and development. Moving Toward a New Century. Ottawa, Ontario, Canada: Centre for Food and Animal Research; 1995. pp. 377-93.

17. Matte JJ, Robert G, Girard CL, Farmer C, Martineau GP. Effect of bulky diets based on wheat bran or oat hulls on reproduc- tive performance of sows during their first two parities. J Anim Sci 1994;72:1745-60.

18.Danielsen V, Vestergaard EM. Dietary fiber for pregnant sow: effect on performance and behavior. Anim Feed Sci Technol 2001;90:71-80.

19. Renteria-Flores JA, Johnston LJ, Shurson GC, Moser RL, Webel SK. Effect of soluble and insoluble dietary fiber on embryo survival and sow performance. J Anim Sci 2008;86:2576-84.

20. Sapkota A, Marchant JN, Richert BT, Lay DC. Including dietary fiber and resistant starch to increase satiety and reduce aggression in gestating sow. J Anim Sci 2016;94:2117-27.

21. Klaver J, Van Kempen GJM, De Lange PGB, Verstegen MWA, Boer H. Milk composition and daily yield of different milk components as affected by sow condition and lactation/feeding regimen. J Anim Sci 1981;52:1091-7.

22. Jackson JR, Hurley WL, Easter RA, Jensen AH, Odle J. Effects of induced or delayed parturition and supplemental dietary fat on colostrum and milk composition in sows. J Anim Sci 1995;73:1906-13.

23. Daza A, Riopérez J, Centeno C. Short communication. Changes in the composition of sows' milk between days 5 to 26 of lactation. Span J Agric Res 2004;2:333-6.

24. Fulks RM, Li JB, Goldberg AL. Effects of insulin, glucose, and amino acids on protein turnover in rat diaphragm. J Biol Chem 1975;250:290-8.

25. Weldon WC, Lewis AJ, Louis GF, Kovar JL, Miller PS. Postpartum hypophagia in primiparous sows. II. Effects of feeding level during gestation and exogenous insulin on lactation feed intake, glucose tolerance, and epinephrine stimulated release of nonesterified fatty acids and glucose. J Anim Sci 1994;72: 395-403.

26.Le CY, David C, Beaumal V, Johansen S, Dourmad JY. Effect of the feeding level during rearing on performance of Large White gilts. Part 2: Effect on metabolite profiles during gestation and lactation, and on glucose tolerance. Nutr Dev 1998;38: 377-90.

27.Long HF, Ju WS, Piao LG, Kim YY. Effect of dietary energy levels of gestating sows on physiological parameters and reproductive performance. Asian-Australas J Anim Sci 2010;23: 1080-8. 